\title{
腰部脊柱管狭窄症再手術例の検討
}

\author{
成尾整形外科病院 \\ 小柳 英一・成 尾 政 图 \\ 浦 門操・田 岡 祐二 \\ 野上俊光・平野拓 志
}

\section{Clinical Study of Multiply Operated Back for Lumbar Canal Stenosis by}

\author{
Eiichi Koyanagi, Masakuni Naruo, Misao Urakado, \\ Yuji Taoka, Toshimitsu Nogami and Takushi Hirano \\ Naruo Orthopedic Hospital, Kumamoto City
}

\begin{abstract}
This study investigated the operative results and factors involved in multiply operated back cases (M.O.B.). 639 cases of Lumbar canal stenosis were surgically treated over a 5 year period, 32 of whon (4.9\%) were M.O.B.. Average improvememt rate according to the J.O.A. score using Hirabayashi's method was $52.0 \%$. Many factors are involved with M.O.B.. The prinapal factors were instability at the affected level and insufficient decompression of lateral recess. It is relatively easy to resect adhesions in new stenotic damage, with an improvement rate was $53.7 \%$. However, when the stenosis is long-term, with scar formation or compression on the dura and nerve root it is very difficult to release the nerve. In these cases, the improvementrate was $20 \sim 30 \%$. For the prevention of M.O.B., adequate decompression and accurate fusion are necessary at the first operation.
\end{abstract}

Key words : Lumbar Canal Stenosis（腰部脊柱管狭窄症), Multiply Operated Back (再手術例), Surgical Results（手術成績）

はじめに

腰部脊柱管狭窄症 (lumbar Canal Stenosis 以下 LCS と略す）は退行変性を基盤としており手術後も 変性は進行する. 手術法としては, 除圧が主体となる ため脊柱の変化は加速されることも考えられる．その 防止策として，固定を行うか否かが問題となる，LCS 再手術 例の成績, 再手術に至った因子について検討 し, 再発防止について考察した。

\section{対}

\section{象}

1992 年から 1996 年迄の 5 年間における LCS 手術 症例は 639 例で再手術例は 32 例（4.9\%）であった。
症例は Degenerative, latrogenic のものを含め, Central Type, Lateral Typeに分類し, 过り部が 関与しているものは変性之り, 分離・过りとし, ヘル ニアが存在したものはへルニア合併とした. Lateral Type が 14 例 (43.5\%) と多く, Central Type は 7 例 $(21.8 \%)$ に，ヘルニア合併は 6 例 $(18.7 \%)$ にみ られた.

その他变性过り 3 例 $(9.3 \%)$, 分離・过り 2 例 （6.2\%）であった（表 1). 性別では, 男性, 女性共 16 例づつであった。年齢は 23 才から 80 才平均 64.2 才で 60-70 代に多くみられた。初回手術より再手術 までの期間は最短 0.3 年最長 18 年, 平均 4.7 年であっ た. 受けた手術回数は 2 回が 28 例 (87.5\%) 3 回が 
4 例（12.5\%）であった. 4 回以上はなかった.

\section{発 症 高 位}

初回手術時には $\mathrm{L}_{4-5}$ 高位が最も多かったが再手術 時では, $\mathrm{L}_{4-5}$ は減少し, $\mathrm{L}_{3-4}$ 高位が増加し, $\mathrm{L}_{5-\mathrm{s}}$ も増加していた（表 2)．多椎間障害例は減少してい た。初回時と同一高位障害を示したものは 23 例 (71.8\%) でそのうち同一病態を示したものは 15 例で 8 例は同一高位でも病態に変化がみられた。隣接高位 発症は 9 例 (28.2\%) 上位発症 7 例下位発症 2 例と上 位に発症しやすい傾向がみられた。

\section{病態}

同一高位では，外側性狭窄が 13 例（56.5\%）ともっ とも多く中心性狭窄は 3 例（13.3\%）であった．变性 过り部障害む 3 例（13.3\%）にみられた，同一高位で のヘルニア合併は 2 例 $(8.6 \%)$ であった。分離・过 りによるあのは 2 例 $(8.6 \%)$ であった。隣接高位で は，中心性狭窄が 4 例（44.4\%）にみられ，外側狭窄 は1例（11.1\%）のみであった。いずれも上位に発症 していた。へルニア合併は 4 例 $(44.4 \%)$ にみられ上 位 2 例, 下位 2 例であった（表 3 ）。

\section{手 術 術式}

初回手術では Love 法, 片側椎弓切除, 拡大空開な ぞ比較的侵襲の少ない手術法が選択される傾向であっ

\begin{tabular}{|c|c|c|}
\hline 表 1 症例 & $-1992-1996-$ & $\frac{32}{639} 4.9 \%$ \\
\hline • 中心性狭窄 & 7 & (21.8\%) \\
\hline - 外側性狭窄 & 14 & (43.5\%) \\
\hline ・変性之一 & 3 & ( $9.3 \%)$ \\
\hline ・ヘルニア合併 & 6 & $(18.7 \%)$ \\
\hline - 分離 - 过り & 2 & ( $6.2 \%)$ \\
\hline 計 & 32 & \\
\hline
\end{tabular}

表 2 高位別頻度（\%)

\begin{tabular}{|c|c|c|c|}
\hline \multicolumn{2}{|c|}{ 初回手術時 } & \multicolumn{2}{|r|}{ 再手術時 } \\
\hline \multirow{2}{*}{$20(62.5)$} & $2(6.2) \square$ & $L_{3-4}$ & $\square 9(28.1)$ \\
\hline & & $L_{4-5}$ & $\square$ 13(40.6) \\
\hline & $2(6.2) \square$ & $L_{5-S}$ & $\square 6(18.7)$ \\
\hline & $1(3.1)$ & $L_{2-3}+L_{3-4}$ & $1(3.1)$ \\
\hline & $3(9.3) \square$ & $L_{3-4}+L_{4-5}$ & $\square 2(6.2)$ \\
\hline & $3(9.3) \square$ & $L_{4-5}+L_{5-S}$ & 0 \\
\hline & $1(3.1)$ & ${ }_{-3}+L_{3-4}+L$ & $5] 1(3.1)$ \\
\hline
\end{tabular}

表 3 病 態 (\%)

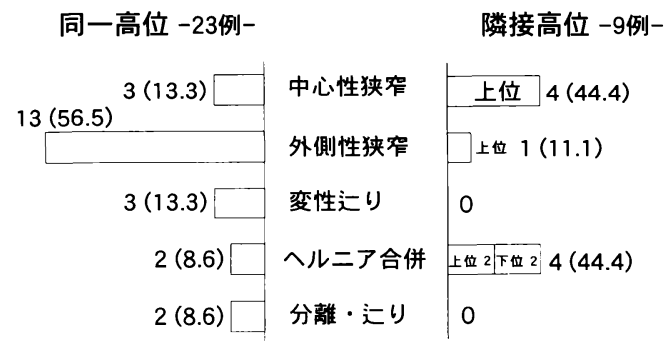

た. 固定が行われたのは後側方固定 6 例之前方固定 1 例の計 7 例（21.8\%）であった。再手術時には除圧の み 21 例 $(65.6 \%)$ 固定術併用が 11 例 (34.3\%) であっ た.

\section{手 術 成 績}

再手術後の成績を JOA Score（改善率は平林法） にて評価した。術前は最低 3 点, 最高 17 点平均 11.7 点であった. 術後は最低 10 点最高 27 点平均 20.7 点 であった．その改善率は $52.0 \%$ あっった，再手術では 硬膜, 神経根の圧迫因子が除去されるか否かが成績を 左右する．主に可動性を原因として新たに生じて来た 㹨窄では神経剥離も比較的容易であり改善率も良かっ た．長年にわたって生じた瘕痕や骨性增殖，除圧不足 が長期に及んだ例での剥離は困難で神経自体む痏痕化 し固定術を併用しても改善率は 20３0\%代と低かっ た.

初回手術後の症状改善度で I 群 : 症状消失, II 群 : 症状軽快（ADL 障害なし）群：症状やや軽快（一 部 ADL 障害あり), IV群 : 症状不变増悪にわけ再手 術後の成績を検討するとその改善度は，I 群 $61.8 \%$, II 群 52.9\%, III群 42.9\%, IV群 37.2\%となり初回手術 時の症状改善のよいものほよ゙再手術時の成績もよかっ た. 初回手術の重要性を示すものと考える.

\section{発症因子}

同一発症高位と隣接発症高位について検討した，発 症因子としてまず春柱の可動性異常が問題となる．可 動性の指標とし Nachemson ${ }^{2)}$ の基準を用いた，X線 側面前後屈像で $\mathrm{L}_{1-2} \sim \mathrm{L}_{4-5}$ は $10^{\circ}$ 以上 $\mathrm{L}_{5-\mathrm{s}}$ は $20^{\circ}$ 以 上の動き, 过りは $\mathrm{L}_{1-2} \sim \mathrm{L}_{4-5}$ は $3 \mathrm{~mm}$ 以上 $\mathrm{L}_{5-\mathrm{s}}$ は $4 \mathrm{~mm}$ 以上を可動性異常とした。同一高位発症群では, 13 例（56.5\%）に可動性増大，後方之り 1 例（4.3\%） 
がみられた．除圧範用不足も8例（34.7\%）にみられた。 特に过りを有するものでは, 中心部の除圧のみで外側症 状の残存がみられた，骨性增殖によるもの 3 例（13.0\%） 瘢痕, 癒着によるもの 5 例（21.9\%）がみられた。退 行性変化の進行によると考えられるものも 3 例 （13.0\%）みられた（表 4).

隣接高位に関しては同部の可動性異常が 5 例 （55.5\%）に認められた。初回手術時狭窄所見がみら れるも症状に無関係として処置を加えなかった例の発 症が 3 例 (33.3\%) にみられた。主病巣の固定不動化 による影響も 3 例（33.3\%）にみられた（表 5)。

\section{心因性 要 因}

腰痛疾患では，重要な因子であり疾病の重症度が心 因性要素を増大させる事もある.

我々は東邦大式 SRQ-D, CMI を日常診療に応用し ている. SRQ-D, 11 点以上の border line を示すむ のが 5 例（16.0\%）であったが，16点以上（軽症うつ 症）の屯のは 1 例 $(4.0 \%)$ のみであった。これら症 例の改善率は $44.0 \%$ であった。
表 4 発症因子

- 同-高位 23 例 - （\%) 複数

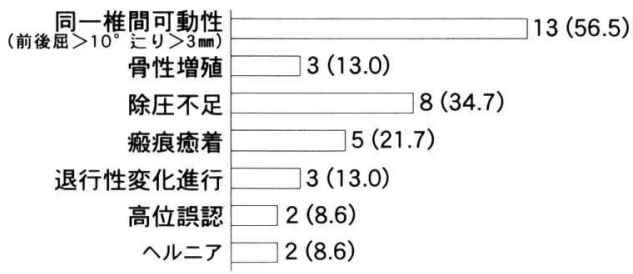

表 5 発症因子

一隣接高位 9 例 - （\%) 複数

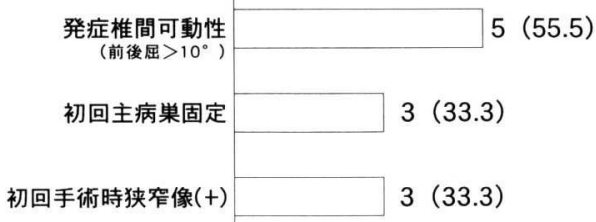

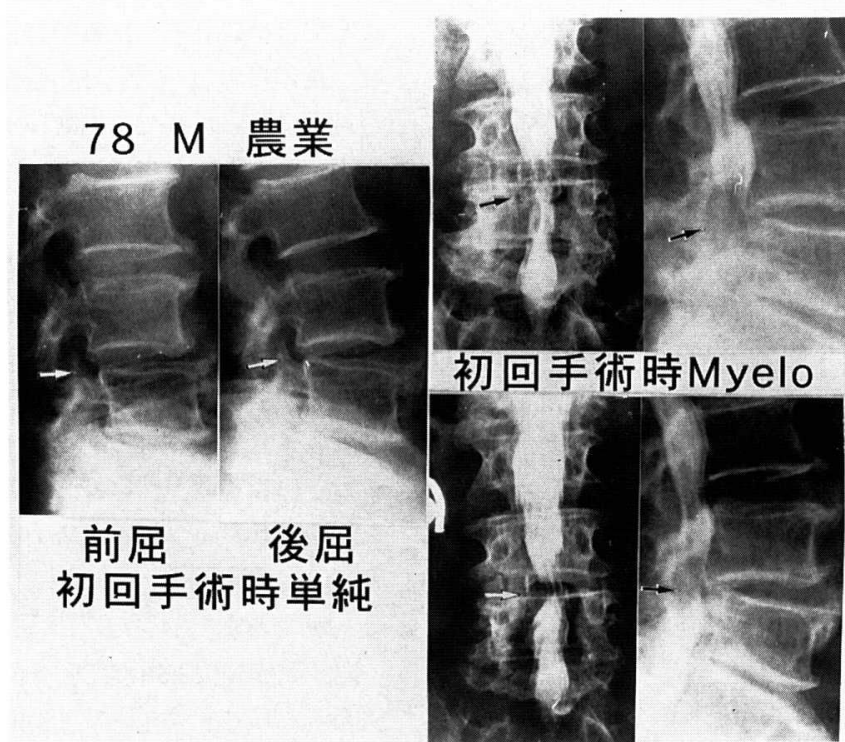

再手術時Myelo
図 1

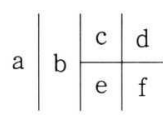

a, b : 椎間可動性異常を認める.

$\mathrm{c}, \mathrm{d}: \mathrm{L}_{4-5}, \mathrm{~L}_{5-\mathrm{s}}$ 狭窄像之 $\mathrm{L}_{4-5}$ から $\mathrm{L}_{5}$ 椎体部の圧排がみら れる.

e, f : L4-5での圧排像がみられる. 


\section{職業的，日常生活因子}

再発には手術後の活動性も充分考慮する必要がある。 初回術後の職業では重労働に従事するものが $40.6 \%$ に みられた. QOL の高まりと共に高㱓者の活動屯活発 となり，スポーツ活動中の発症もみられた.

症例

症例 1,78 才, 男性, 農業.

76 才時ゲートボール中右䳑部から下肢痛出現. 単 純 X線機能撮影で異常可動性, 後方沪りを認める. エログラフィーでは, $\mathrm{L}_{4-5}, \mathrm{~L}_{5-\mathrm{s}}$ 狭窄を認める. 術 中 $\mathrm{L}_{4-5} \mathrm{~L}_{5-5}$ の狭窄と共に $\mathrm{L}_{4-5}$ より下方へ逸脱した ヘルニアを認めた．高齢のため固定は行わなかった。 6 ケ月後同高位に再発がみられた。初回手術時可動性 異常を認め, 活動性も高く固定すべきであったと考え る(図 1 ).

症例 2, 64 才, 女性, 建設業.

48 才の時 $\mathrm{L}_{4}$ 椎弓切除術を受けている. 16 年後頃よ り腰部伸展障害, 下肢痛, シビレ出現. ミエログラフィー では $\mathrm{L}_{3}$ 下緑より $\mathrm{L}_{4}$ 椎体中央にかけ石灰化陰影と通過 障害を認める。術中所見で硬膜に癒着した瘷痕と骨様 組織がみられた（図2）.

症例 3,74 才, 女性, 主婦.

66 才時左下肢痛, 筋力低下出現し, 椎弓切除受け るも症状不変であった．特に治療受けず放置していた。 8 年後受診時左下肢麻痺，歩行不能であった。単純X 線では, 中心部に椎弓切除痕跡を認め, ミエログラ フィー, CTM では中心部のみの通過がみられた。除 圧範囲の不足が原因と考えられた（図 3 ）.

\section{考察}

LCS 再発例の病態と発症因子について検討した。 同一高位発症例が多くみられたがこれらでは瘢痕, 癒着 が生じており診断, 手術操作の困難さが問題となる。病 態としては, lateral stenosis が多い事はBurton ${ }^{1)}$ はじめ多くの報告がある ${ }^{2) 6)}$. 我々の症例でも除圧不 足は lateral pecess の除圧不足で特に过り例では中 心部の除圧のみによるものが多かった。術前の CT.や 神経根造影で病態を確認しておく必要がある. 発症に 複数の因子が関与する事は，横山らも述べている，特 に椎間不安定性は大きな要因として多くの報告がみら れる，高齿者においては，椎間板の狭小化，骨䊂形成。

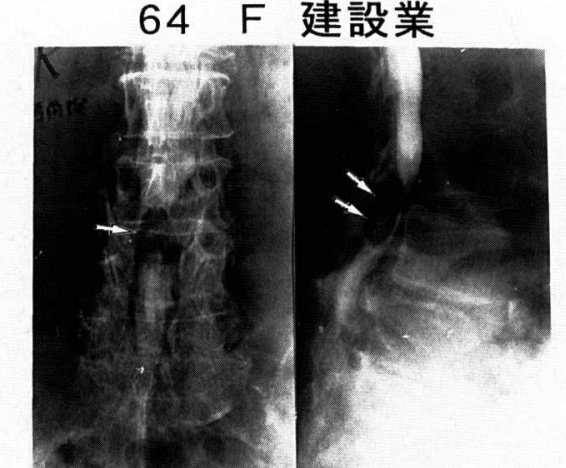

\section{再手術時Myelo}

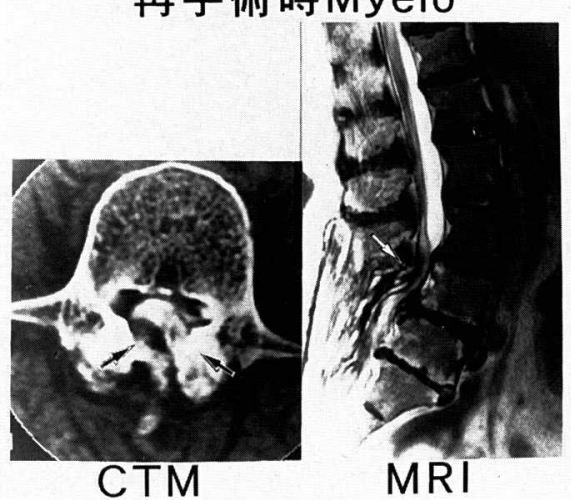

图 2 a b a , b , d : L , 加 L 椎体 かけ後方からの圧迫がみられ る.

c : 椎間関節の著名な肥厚之, 骨 化を含む，後方圧迫がみられ る.

椎間関節の变性等により椎間比可動域にはばらつきが みられるが同一高位例では $\mathrm{L}_{3-4}, \mathrm{~L}_{4-5}$ に増大がみら れ隣接例では $\mathrm{L}_{3-4}, \mathrm{~L}_{5-\mathrm{s}}$ に増大がみられた。程度の 指標として今回は Nachemson の基準を参考とした. 初回手術時固定を併用するかどうかには，異論がみら れる，不安定性は他の因子を増強させると考えられ， 椎間板への侵襲を行った時，椎間関節の $1 / 2$ 以上の切 除を要した時, 椎間可動性の異常を認める時は固定術 を併用した方がよいと考える.

固定法は除圧範囲が狭いときは棘間スペーサー固定 （椎間関節固定を併用することもある），広範囲椎弓切 除では後側方固定, angular instability が高度の場 合は前方椎体固定術で対応している. Instrumentationは原則として行っていない. 


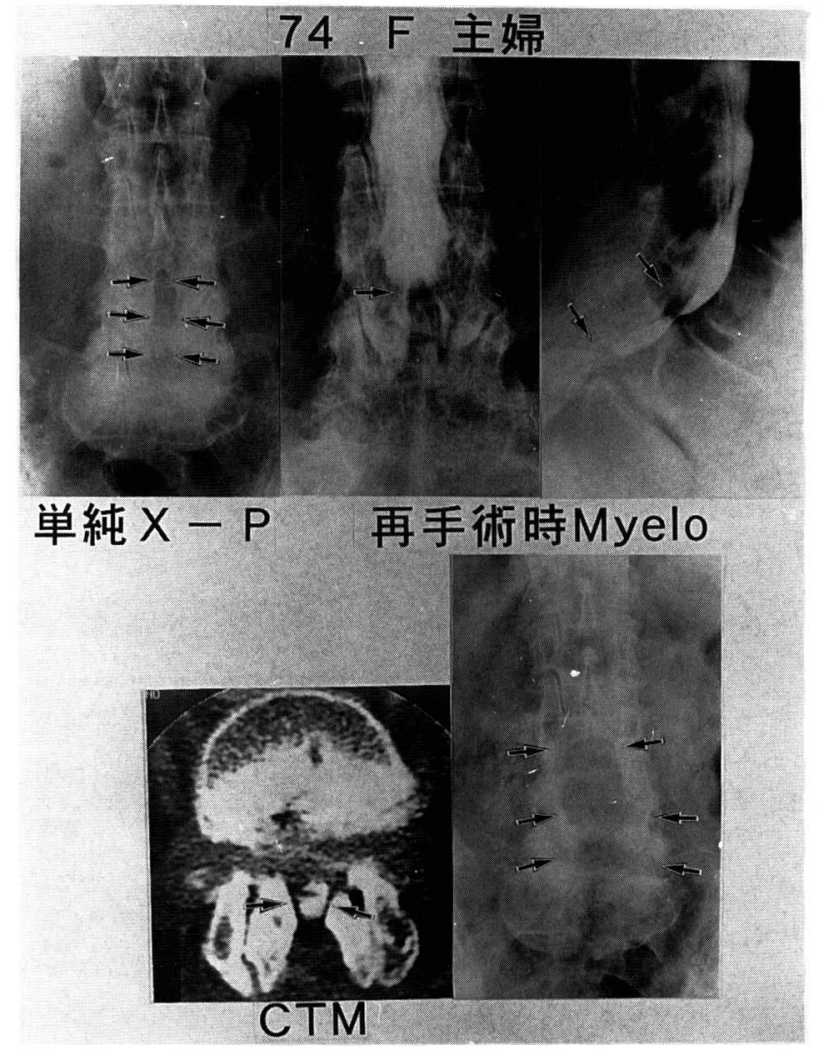

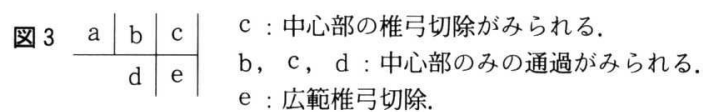

症状に直接関係する骨性増殖，洀痕形成，癒着は少 ないが, 硬膜, 神経根との強度の癒着を完全に切除す ることは困難であり，硬膜自体の硬化のため正常に膨 隆する事はない，馬尾の癒着の成績不良は横山・金田 らも述べている. 我々は硬膜内操作は行っていない. 又直接発症に関与していなくても神経根の不動性を生 じ, 他の要因が加味され発症する事も考えられ, 術中 の愛護的操作, 充分の止血之脂肪移植が必要と考える. 隣接高位発症では可動性異常と共に後法过りを呈する あのが多かった. 又, 初回主病巣固定が 4 例に施行さ れたがそのうち 3 例は手術時狭窄所見みられるも症状 に無関係として処置を行なわなかったものである．野 原は, 隣接椎間に狭窄がある場合, 椎間の不安定性を 損なわない範囲で除圧を加えるとしているが，これら を病巣の一部として手操操作を加えるから゙うか問題と なる. 又, 野原, 横山らも述べているごとく心因性要 素も充分考慮し術後の職業はじめ, ADL 指導の重要
性も感じられた。

$$
\text { ま と め }
$$

LCS 再手術 32 例について成績, 要因について検討 した. 成績はJOA Score 平林法で改善率 $52.0 \%$ であっ た. 発症因子としては, 複数の要因が関与していると 思われる. 特に脊柱可動性の異常が大きな因子と考え られ初回手術時椎間板操作, 椎間関節切除, 可動性異 常を認める場合においては固定を併用すべきと考える. 隣接発症防止には病態にあわせ対処する以外決定的方 策はない。

\section{参考 文 献}

1) Burton, C. V., et al. : Couses of failare surgery on the lumbar spine. Clinical Orthop., 157 : 191-199, 1981.

2）金田 清志: 腰部脊柱管狭窄症における術後成績不良 例の病態と再手術. 整形外科 MOOK，41．299-311, 
1985

3) Nachemson, A. : The rule of spine fusion : question 8 Spine, $6: 306-307,1981$.

4）野原 裕: 術後成績不良例 (MOB)の病態之対策. Orthopedics, $6: 95-104,1993$.

5）佐藤日出夫：postoperative spinal stenosis の臨床的
検討. 整・災外, 35：1203-1209, 1992.

6）渡分栄一・菊池臣一：腰部脊柱管狭窄症成績不良例の 検討. 臨整外, $29: 707-713,1994$.

7）横山 浩他：腰部脊柱管狭窄症の再手術例の検討。臨 整外, $27: 465-471 ， 1992$. 